\title{
DUA MAZHAB EMANASI DALAM FILSAFAT ISLAM KLASIK DAN IMPLIKASI TEOLOGISNYA
}

\author{
Ibnu Ali \\ Universitas Islam Madura, Indonesia \\ E-mail: ibnualialfarabi@gmail.com
}

\begin{abstract}
Islamic philosophy, which has been an accumulation of relation between pure logic and religious texts (naq), has a uniquely different features from the philosophy of Aristotle. This is because the Islamic philosophy has met not only with the pre-Islamic sciences but it also has thoroughly interacted with various branches of the Islamic knowledge such as theology, tasamwn, usûl al-figh, and târk̂h al-tashrî. The interaction has resulted in numerous different thoughts within the Islamic philosophy itself as can be identified among the peripatetic Islamic philosophers. The article is intended to describe that in discussing cosmological matter, the majority of these philosophers put emphasis on Plotinus's concept of emanation. However, the concept has led to distinctively diverse schools of philosophy in Islam. The study finds that the philosophers with strong background of scientific disciplines produced considerably different thought of emanation from those with strong background of Islamic knowledge. The first school consists of scientists-philosophers affiliated to the thought of Pythagoras, Plato, and Aristotle though with new concepts they proposed. The second school comprises Sufi-philosophers whose concepts have been strongly influenced by intuition though there have been conceptual differences based on their spiritual experiences.
\end{abstract}

Keywords: Islamic philosophy; emanation; theological implications.

\section{Pendahuluan}

Islam dalam waktu yang singkat berkembang dari hanya persoalan agama kepada persoalan budaya dan peradaban, terutama di masa Bani Umayyah dan Bani 'Abbâsîyah. Melalui akulturasi kebudayaan Yunani, Persia, dan India pada sekitar abad ke-8 hingga $10 \mathrm{M}$, aktivitas ilmiah 
umat Islam meningkat secara ekspansif. Adanya dorongan dari faktor internal ajaran agama Islam membuat umat Islam tidak hanya memfokuskan perhatian mereka pada ilmu keislaman saja, tetapi juga fokus pada ilmu-ilmu pra-Islam. Selama kurang lebih dua abad dari tahun 750-1000 M banyak karya-karya metafisik, filosofis, dan karya ilmiah lainnya yang tak terhitung jumlahnya diterjemahkan ke dalam bahasa Arab dari bahasa Yunani, Suryani, Pahlavi dan Sanskrit. Beberapa penerjemah ulung dari agama lain dilibatkan dalam proses penerjemahan itu seperti Hunayn b. Ishâaq dan Thâbit b. Qurrah yang berasal dari agama Zoroaster. ${ }^{1}$ Kegiatan penerjemahan ini menjadi pintu masuknya kebudayan Yunani sehingga Islam mulai mengenal term filsafat dalam kajian keislaman.

Kehadiran filsafat dalam kajian keislaman tidak hanya karena adanya faktor internal, tapi juga faktor eksternal. Kontak pemikiran pada era itu terjadi antara umat Islam dengan otoritas-otoritas keagamaan Yahudi dan Kristen yang berusaha mempertahankan ajaran-ajaran keimanan mereka. Mereka menyerang ajaran-ajaran Islam dengan menggunakan argumenargumen logika dan filsafat Yunani Aristotelian yang sama sekali belum dikenal umat Islam. Maka dalam usaha untuk memperkuat keimanan Islam, umat Islam menggunakan perisai intelektual dari jenis yang sama. Logika Aristoteles dan beragam filsafat Yunani lainnya mengalir deras ke dunia Islam melalui arus penerjemahan yang sedang digiatkan pada waktu itu, sehingga dengan demikian dapat melindungi kekuatan sharî‘ah, tempat bergantungnya otoritas mereka sendiri. ${ }^{2}$

Keadaan ini membuat pemikiran Islam yang semula murni berdasarkan agama berbaur dengan pemikiran filsafat. Kata filsafat mulai disandingkan dengan Islam, meski pada dasarnya filsafat adalah pemikiran murni yang berdiri sendiri dan lepas dari tradisi, budaya, dan agama. Namun kontak ini secara riil telah menghasilkan argumenargumen agama yang filosofis atau argumen-argumen filsafat yang didukung dengan argumen agama. Seperti argumen-argumen penciptaan alam semesta yang dimunculkan para filsuf Islam. Bagaimana proses penciptaannya dan apa diciptakan dari ada (Creatio Nibilo) atau dari tiada (Creatio ex-Nibilo). Maka dalam beberapa pembahasan, para filsuf Islam

1 Seyyed Hossein Nasr, Tiga Mąhab Utama Filsafat Islam: Ibnu Sina, Subrawardi, dan Ibn Arabi (Yogyakarta: IRCiSoD, 2014), 12.

2 Ibid., 13. 
menghadirkan argumentasi agama dan filsafat untuk menunjukkan bahwa filsafat tidak bertentangan dengan ajaran agama.

Meski demikian, term filsafat Islam belum sepenuhnya diterima, bahkan mendapat kritikan dari sebagian pemikir, di antaranya adalah Maurice de Wulf dalam bukunya Histoire de Philosophic Mediavale (Sejarah Filsafat Abad Pertengahan) dan Emile Brehier dalam bukunya Histoire de la Philosophic (Sejarah Filsafat) dari penulis Barat. Dari penulis Islam sendiri ada Lutfi al-Sayyid dalam mukaddimah-nya terhadap terjemahan Aristoteles, Etika untuk Nukomakus. Semua pemikir tersebut lebih menyetujui term filsafat Arab dari pada filsafat Islam. ${ }^{3}$

Kritik terhadap term filsafat Islam tersebut menurut Carlo Nallino setidaknya karena dua alasan. Pertama, term Islam akan mengeluarkan penulis-penulis Yahudi, Kristen, Șâbi'ah, dan agama-agama lain yang memberikan kontribusi yang tidak sedikit terhadap perkembangan ilmu dan karya-karya Arab, terutama dalam lapangan matematika, astronomi, kedokteran, dan filsafat. Kedua, karya-karya yang ada pada waktu itu ditulis dengan bahasa Arab meski penulisnya antara lain adalah orangorang Persia. Jadi bahasa Arab yang mempertalikan karya-karya mereka sehingga tidak tepat jika filsafat itu dinisbatkan pada umatnya. ${ }^{4}$

Namun demikian, beberapa penulis Barat lainnya lebih setuju dengan term filsafat Islam. Mereka antara lain adalah Max Horten dalam Encyclopedia Islam, De Boer dalam The History of Philosophy in Islam, Gauthier dalam Introduction a'T'etude de la Philosophic Musulmane, dan Carra Devaux dalam Les Penseur de I'Islam. Alasannya adalah karena kebanyakan tokohnya bukan dari keturunan semit atau Arab, tapi keturunan Persia, Turkistan, dan lain-lain. Filsafat mereka dipertalikan dengan Islam karena agama Islam mempunyai pengaruh signifikan terhadap perkembangan ilmu pengetahuan dan filsafat. Perkembangan filsafat tersebut berada di negeri-negeri Islam dan di bawah naungan Islam. ${ }^{5}$

Produk filsafat yang memasuki periode Islam itu memang bukan berasal dari orang Arab semata, apalagi pusat pemerintahan Islam berada di tengah-tengah Persia, tempat di mana ilmu-ilmu pra-Islam dikembangkan. Bukan pula semata-mata karena umat Islam. Sebab

\footnotetext{
3 Atang Abdul Hakim, Filsafat Umum: dari Mitologi sampai Teofilsofi (Bandung: Pustaka Setia, 2008), 439.

4 Ibid., 440.

5 Ibid., 439.
} 
perkembangan ilmu tersebut sangat bersentuhan sekali dengan keberadaan umat-umat lain. Namun secara kronologis, pemikir Islam pada awalnya berguru pada aliran Nestorias, Yacobias dari golongan Kristen, Yahudi, dan penganut agama Șâbi'ah. Dalam aktivitas ilmiah tersebut, interaksi dengan umat Yahudi dan Kristen masih dilakukan umat Islam.

Ibrâhîm Madhkûr dalam hal ini memberikan uraian bahwa term filsafat Arab tidak untuk menunjukkan produk suatu ras atau umat. Menurutnya, term filsafat Islam lebih tepat dan lebih utama dari pada filsafat Arab. Sebab Islam bukan hanya sebagai agama yang menyangkut masalah akidah saja, akan tetapi lebih dari itu adalah sebagai peradaban dan kebudayaan. Setiap peradaban memiliki bentuk dan karakternya sendiri baik dalam aspek moral, material, intelektual, dan emosional. Peradaban Islam pasti memberikan pengaruh terhadap corak dan karakter pemikiran yang dikembangkan pada masa itu, sehingga apa yang dimaksud dengan filsafat Islam adalah mencakup seluruh studi filosofis yang ditulis di dunia Islam meski ditulis oleh orang-orang Yahudi dan Nasrani. ${ }^{\circ}$ Sebagaimana diperkuatkan oleh pendapat Tara Chand, penulispenulis kitab filsafat dari kalangan Yahudi dan Nasrani yang bersifat kritis maupun yang terpengaruh oleh Islam lebih baik jika dimasukkan pada filsafat Islam. ${ }^{7}$

Filsafat Islam merupakan akumulasi dari persentuhan antara akal murni dengan sumber otoritatif agama. Sidi Gazalba menggambarkan bahwa Tuhan memberikan dua jalan kebenaran kepada manusia, yaitu akal dan naql. Akal membentuk pengetahuan yang bersifat rasional, sedangkan naql memberi pengetahuan yang irasional dan transenden. Menurutnya, apabila pengetahuan akal itu digerakkan oleh naql maka ia menjadi filsafat Islam. Pengetahuan naql yang tidak bisa dibuktikan dengan riset ilmu pengetahuan, maka penjelasannya dapat dicarikan dalam filsafat Islam. ${ }^{8}$ Bisa disimpulkan filsafat Islam adalah filsafat yang bercampur dengan Islam dalam membahas segala sesuatu.

Dengan demikian filsafat Islam telah menampilkan mazhab baru yang secara mandiri memisahkan diri dari filsafat Yunani meskipun harus diakui bahwa kemunculan filsafat Islam tidak bisa dilepaskan dari adanya

\footnotetext{
${ }^{6}$ Fuâd al-Ahwânî, al-Falsafah al-Islâmîyah (Kairo: Dâr al-Qalam, t.th.), 15.

${ }^{7}$ A. Mustofa, Filsafat Islam (Bandung: Pustaka Setia, 1997), 17.

8 Sidi Gazalba, Sistematika Filsafat (Jakarta: Bulan Bintang, 1976), 31.
} 
pengaruh filsafat Yunani tersebut. Filsafat Islam memiliki karakter khas tersendiri yang berbeda dari filsafat Aristoteles, seperti dalam pemikiran teologi dan tasawuf. Keunggulan khas filsafat Islam dapat dilihat dari pembagian cabang-cabangnya yang mencakup ilmu kedokteran, biologi, kimia, musik, matematika dan astronomi. Bahkan filsafat Islam memasuki cabang ilmu-ilmu keislaman yang mencakup teologi, tasawuf, ușul al-fiqh, dan târikh al-tashrî.

Adanya multi-disiplin keilmuan dalam filsafat Islam ini mempengaruhi terhadap pembahasan-pembahasan filsafat Islam sehingga memunculkan corak mazhab yang beragam. Ada mazhab filsufilmuwan di mana pemikiran filosofis dipadu dengan pengetahuan saintifik seperti yang terdapat pada al-Fârâbî, Ibn Sînâ, Ibn Miskawayh, dan Ikhwân al-Ṣafâ. Ada mazhab filsuf-teolog, di mana argumentasi filosofis digerakkan untuk mempertahankan pemikiran teologis, seperti al-Ghazâlî. Ada mazhab filsuf-sufi, di mana pemikiran filosofis dipadu dengan petunjuk-petunjuk intuisi, seperti Suhrawardî al-Maqtûl dan Ibn 'Arabî. Dari ketiganya ada dua mazhab yang tertarik terhadap pembahasan kosmologi dengan menggunakan teori emanasi, yaitu mazhab filsuf ilmuan dan filsuf sufi.

\section{Embrio Filsafat Emanasi}

Emanasi (fayd) adalah teori tentang keluarnya suatu wujud yang mumkin dari Dhât yang Wajìl al-Wujûd. ${ }^{9}$ Teori ini bisa disebut dengan pembahasan tentang asal segala yang ada. Teori ini banyak mendasari sistem berpikir para filsuf selama berabad-abad mulai dari Barat klasik sampai ke dunia Islam di Timur. Para filsuf Islam banyak yang terpengaruh dengan teori ini. Bagaimana sesungguhnya teori ini muncul dalam pemikiran Islam?

Ada tiga mazhab pemikiran yang pernah hidup di Yunani sebelum para filsuf besar berikutnya bermunculan di kawasan itu. Pertama, mazhab Ionik. Salah seorang filsufnya adalah Thales dari Miletus yang menyatakan bahwa asal segala benda adalah air. Anaximenes, filsuf lainnya dari Milesian memandang bahwa udara menjadi penyebab segala sesuatu. Kedua, mazhab Dorik dengan filsufnya Phytagoras yang memandang bilangan sebagai penyebab pertama. Mazhab terakhir adalah Eleatik dengan Xenophenes sebagai filsufnya yang memandang Tuhan sebagai satu dan segalanya. Zeno merupakan filsuf pertama

\footnotetext{
${ }^{9}$ Hakim dan Saebani, Filsafat Umum, 460.
} 
dari pemikir ini yang menyatakan adanya dunia yang tidak nyata dan realitas mutlak. ${ }^{10}$

Keadaan ini berlangsung hingga Plato dengan konsepnya tentang dunia ide dan Aristoteles. Namun kenyataan tentang adanya hubungan Tuhan dengan alam atau antara alam dengan realitas mutlak yang tidak nyata itu dapat ditemukan dalam gagasan Philon al-Iskandarî (25-45 SM). Gagasan filsafatnya banyak mengambil dari kitab perjanjian lama. ${ }^{11}$ Menurutnya Tuhan itu maha tinggi dan karena begitu tinggi kedudukannya perlu ada perantara yang menghubungkan antara Tuhan dengan alam semesta. ${ }^{12}$ Perantara ini disebut dengan logos pertama yang merupakan manifestasi Tuhan seperti yang tertulis dalam Injil Yohanes. ${ }^{13}$ Dari logos dunia yang banyak ini muncul. Kemunculan dunia ini mengalir melalui lima tahapan, yaitu Tuhan, logos atau akal pertama, jiwa, alam mithal, dan alam semesta. ${ }^{14}$ Semua ini muncul dari logos pertama tersebut.

Selain itu, Plotinus (205-270 SM) pendiri mazhab neo-Platonisme, juga disebut-sebut sebagai filsuf yang mengawali teori emanasi. Dia awalnya ingin memperdalam filsafat Plato, sehingga mazhabnya dikenal dengan Platonisme. Gagasan filsafatnya berpusat pada keyakinan bahwa segala sesuatu berasal dari Yang Satu. Alam semesta ini muncul secara melimpah dari Yang Satu itu. Namun yang melimpah itu tetap bagian dari Yang Satu. Yang Satu ini adalah semuanya tetapi semuanya tidak terkandung di dalam Yang Satu. Di dalam yang satu yang banyak itu belum ada, tapi akan ada dan keluar dari yang satu itu menjadi ada. ${ }^{15}$ Tahapan-tahapan kemunculan yang banyak ini melimpah menjadi lima tahapan, yaitu dari Yang Satu, akal, jiwa, tabiat, dan materi kasar. ${ }^{16}$ Memang terdapat kemiripan antara Philon al-Iskandarî dan Plotinus dalam memberikan penjelasan terhadap tahapan-tahapan wujud.

Philon tidak begitu dikenal dibandingkan dengan Plotinus dalam melahirkan teori emanasi. Bisa jadi karena Philon lebih mendahului dengan

10 Khan Sahib Khaja Khan, Cakerawala Tasamuf, terj. Achmad Nashir Budiman (Jakarta: Raja Grafindo Persada, 1993), 41.

${ }^{11}$ Hakim dan Saebani, Filsafat Umum, 123.

12 Ibid., 124.

${ }^{13}$ Khan, Cakrawala Tasamuf, 45.

${ }^{14}$ Ibid., 45-47.

15 Hakim dan Saebani, Filsafat Umum, 126-127.

16 Ibrahim Hilal, Tasanuf antara Agama dan Filsafat: Sebuab Kritik Metodologis, terj. Ija Suntana dan E. Kusdian (Bandung: Pustaka Pelajar, 2002), 135. 
jarak periode yang begitu lama atau memang karena unsur-unsur Hellenisme lebih berpengaruh terhadap dunia Islam dengan sisa-sisa peradabannya yang masih ada pada waktu itu. Namun demikian, para filsuf Islam menunjukkan ketertarikan yang besar terhadap teori ini. Seperti yang dinyatakan oleh Nurcholis Madjid bahwa para filsuf Islam terdorong untuk mempelajari doktrin Plotinus karena ia memberikan kesan tauhid. ${ }^{17}$

Semangat tersebut sejalan dengan dinamika perkembangan pemikiran teologi. Mu'tazilah sebagai salah satu aliran teologi dalam Islam mengembangkan argumen-argumen rasional untuk mempertahankan konsep teologi mereka. Paham ini berkembang sejak awal abad ke 8 M. Corak pemikiran teologi mereka yang bersifat rasional dan liberal diminati kaum intelegensia di lingkungan pemerintahan dinasti 'Abbâsîyah, sehingga dijadikan mazhab resmi negara oleh Khalifah al-Ma'mûn (813-833 M) pada permulaan abad ke 9. Namun Khalifah al-Mutawakkil membatalkannya pada tahun 856 M.18

Mu'tazilah yang memberikan penghargaan yang tinggi terhadap akal memberikan pengaruh bagi perkembangan ilmu pengetahuan. Masa Khalifah Hârûn al-Rashîd (766-809 M) dan al-Ma'mûn (813-833 M) adalah masa perkembangan ilmu pengetahuan di mana Mu'tazilah sedang menjadi mazhab resmi Negara. Al-Mas'ûdî misalnya, seorang ilmuan geografi dalam kitabnya Murîj al-Dhahab memuji ketajaman akal, ketelitian dalam pandangan, dan kejernihan dalam pemikiran. ${ }^{19}$ Di samping itu, konsep-konsep teologi Mu'tazilah dipengaruhi oleh filsafat Yunani, terutama dalam konsep tauhid. Tema ketuhanan menjadi trending topic yang menarik diperbincangkan pada waktu itu.

Di tengah situasi perkembangan paham Mu'tazilah dan pengaruh filsafat Yunani itulah filsafat Islam dimulai. Al-Kindî (801 M) dianggap sebagai filsuf pertama dalam Islam dan mendapat panggilan filsuf Arab. Masa kecilnya sempat merasakan masa pemerintahan Hârûn al-Rashîd yang terkenal sangat mendorong perkembangan ilmu pengetahuan. ${ }^{20}$ Kemudian diikuti oleh filsuf-

\footnotetext{
${ }^{17}$ Nurcholish Madjid, Khazanah Intelektual Islam (Jakarta: Bulan Bintang, 1984), 24.

18 Harun Nasution, Teologi Islam: Aliran-aliran Sejarah Analisa Perbandingan (Jakarta: UI Press, 2012), 10.

${ }^{19}$ Harun Nasution, Akal dan W abyu dalam Islam (Jakarta: UI-Press, 2011), 52.

${ }^{20}$ Mustofa, Filsafat Islam, 99.
} 
filsuf Islam berikutnya, yaitu al-Razi (865-925 M), al-Fârâbî (870-950 M), Ibn Miskawayh (932-1030 M) dan Ibn Sînâ (980-1037 M), dan lain-lain.

Mayoritas filsuf Islam berminat pada konsep emanasi dalam usaha menjelaskan Tuhan dan hubungannya dengan alam semesta. Emanasi ini dianggap dapat melengkapi dan memperkuat konsep tauhid dalam teologi Islam dan pandangan mereka terhadap kosmologi. Wahyu sebagaimana ayat-ayat kawnîah dalam al-Qur'ân hanya menggambarkan masalah kosmologi secara universal. Maka untuk menggambarkannya secara terinci, filsuf Islam mengambil jalan kontempelasi akal. Emanasi adalah teori yang paling representatif dalam menuntaskan persoalan tersebut.

Para filsuf Islam mulai al-Fârâbî, Ibn Miskawyh, Ikhwân al-Ṣafâ, sampai Ibn Sînâ ikut terpengaruh dalam mengembang teori emanasi ini. Bahkan hal demikian terlihat jelas dalam pemikiran tokoh tasawuf falsafi, seperti Suhraw ardî al-Maqtûl dan Ibn 'Arabî. Tetapi Suhrawardî al-Maqtûl mengulasnya dalam bentuk berbeda yang disebutnya dengan istilah ishrâq (iluminasi). Sedangkan Ibn 'Arabî menggambarkannya dalam konsep tasawufnya yang terkenal, yaitu Waḅdat al-Wujüd.

\section{Mazhab Emanasi Filsuf-Ilmuwan}

Sesuai dengan masanya, periode awal filsuf Islam memberikan minat yang besar terhadap ilmu pengetahuan. Mereka pada umumnya adalah filsuf disamping sebagai ilmuwan. Adanya dukungan dari pemerintahan dinasti 'Abbâsîyah ikut memberikan andil dalam mempelajari dan mengembangkan ilmu-ilmu pra-Islam. Al-Kindî misalnya disamping mempelajari filsafat Yunani juga mempelajari ilmu kedokteran, matematika, logika, geometri, dan astronomi. ${ }^{21}$ Namun menurut Massignon, seorang oreintalis Perancis, al-Kindî belum dapat dianggap sebagai filsuf Islam pertama karena dia belum menciptakan sistem mazhab filsafat tertentu dan persoalan-persoalan yang dibicarakannya belum mendapatkan pemecahan yang memuaskan. ${ }^{22}$

Menurut Massignon, filsuf Islam pertama yang dapat dianggap menciptakan sistem filsafat yang lengkap adalah al-Fârâbî. 23 Dia menyusun sistem filsafat dengan mengambil peranan penting seperti

\footnotetext{
21 Ibid., 100.

22 Ibid., 127. Hakim dan Saebani, Filsafat Umum, 448.

23 Ibid., 448.
} 
halnya yang dimiliki Plotinus bagi dunia Barat. Sistem filsafatnya ini membentuk mazhab filsuf-ilmuwan dan memberikan sistem mendasar filsafat yang mempengaruhi pemikiran Ibn Sînâ, Ibn Rushd, dan filsuf Muslim lain sesudahnya. Sehingga dia diberi gelar al-Mu'allim al-Thân̂̂ (guru kedua) di samping Aristoteles yang dianggap sebagai guru pertama.

Beberapa buku tersebut memperlihatkan dengan jelas sosok al-Fârâbî sebagai seorang filsuf yang berminat membicarakan ilmu pengetahuan. Buku yang terakhir diatas menggambarkan hal tersebut. Dalam bukunya Iḥsầ' al-'Ulûm, al-Fârâbî membicarakan beragam ilmu pengatahuan, yaitu ilmu bahasa, logika, matematika, fisika, ilmu ketuhanan, ilmu perkotaan, ilmu fiqh, dan ilmu kalam. Al-Fârâbî menambahan dua pembahasan ilmu yang tidak dididapatkan dari Yunani, yaitu ilmu fiqh dan ilmu kalam sebagai ilmu keislaman yang mendapatkan perhatian yang besar pada masanya, ${ }^{24}$ sehingga al-Fârâbî memberikan susunan filsafat yang lebih lengkap dari pendahulunya, al-Kindî.

Bukunya al-Jam 'bayn Ra'yay al-Hakîmayn memperlihatkan dengan jelas bahwa al-Fârâbî berusaha memadukan pemikiran besar antara Plato dengan Aristoteles yang selama ini dianggap bertentangan. ${ }^{25}$ Bahkan alFârâbî sendiri termasuk filsuf sinkretis yang mempercayai ketunggalan filsafat. ${ }^{26}$ Dia sangat menyayangkan terjadinya aliran-aliran pemikiran dalam filsafat. Padahal tujuannya sama, yaitu mencari kebenaran. Apa yang tampak berbeda sebenarnya hanya aspek lahir saja. Sedangkan dalam persoalan pokoknya, pemikiran kedua tokoh tersebut sama.

Filsafat al-Fârâbî sendiri merupakan campuran antara filsafat Aristoteles, Plato, dan Neoplatonisme yang kemudian dipertemukan dengan pemikiran keislaman. Dalam soal logika dan filsafat fisika dia terpengaruh dengan Aristoteles. Dari Plato dia mengambil filsafat etika dan politik. Sedangkan dari Plotinus, dia tertarik tentang metafisika. Hal ini sebagaimana yang akan terlihat bagaimana cara al-Fârâbî memecahkan persoalan kosmologi dengan filsafat emanasi.

Menurut al-Fârâbî proses terjadinya alam ini memancar dari Tuhan melalui proses ta'aqqul (pemikiran) Tuhan terhadap Dhât-Nya. Allah sendiri dalam filsafat Islam disebut dengan 'aql (ke-mahacerdas-an). Penyebutan ini erat kaitannya dengan keterpesonaan mereka tentang

${ }^{24}$ A. Hanafi, Pengantar Filsafat Islam (Jakarta: Bulan Bintang, 1976), 83.

25 Ibid.

${ }^{26}$ Hakim dan Saebani, Filsafat Umum, 448. 
penciptaan Allah yang sangat sempurna yang tak bisa dibandingkan dengan apa dan siapa pun. Pemikiran Allah terhadap Dhât-Nya sendiri yang Esa merupakan daya yang amat dahsyat. Seperti disebutkan oleh Harun Nasution, bahwa ta'aqqul Allah terhadap Dhât-Nya sendiri itu merupakan ilmu Allah tentang diri-Nya, dan ilmu itu adalah daya (alqudrah) yang menciptakan segalanya. ${ }^{27}$ Maka sesuatu itu bisa tercipta cukup hanya dengan cara sesuatu itu diketahui Allah. Dari daya pemikiran inilah Allah menciptakan alam semesta secara tidak langsung.

Selanjutnya proses ta'aqqul Tuhan terhadap Dhât-Nya ini memembentuk susunan yang sistematis dan hierarkis, yaitu menghasilkan akal-akal yang jumlahnya sepuluh (al-'Aql al-'Asharab). Tuhan berpikir tentang diri-Nya; pemikiran merupakan daya, dan pemikiran Tuhan yang maha kuasa besar dan hebat itu menciptakan akal pertama. Akal pertama berpikir pula tentang Tuhan dan dirinya sendiri, maka daya ini menghasilkan akal kedua dan langit pertama. Akal kedua berpikir juga tentang Tuhan dan tentang dirinya sendiri dan menghasilkan akal ketiga dan bintang-bintang. Begitu pun seterusnya akal-akal berpikir tentang Tuhan dan dirinya sendiri lalu menghasilkan akal-akal berikutnya dan planet-planet. Akal ketiga menghasilkan akal keempat dan Saturnus. Akal keempat menghasilkan akal kelima dan Yupiter. Akal kelima menghasilkan akal keenam dan Mars. Akal keenam menghasilkan akal ke tujuh dan Matahari. Akal ketujuh menghasilkan akal kedelapan dan Venus. Akal kedelapan menghasilkan akal kesembilan dan Merkurius. Akal kesembilan menghasilkan akal yang kesepuluh dan Bulan. ${ }^{28}$ Pada tahapan yang terakhir, yaitu akal yang kesepuluh sudah lemah untuk menghasilkan akal yang sejenisnya dan hanya menghasilkan bumi saja. ${ }^{29}$

Semua akal yang berjumlah sepuluh itu mengatur planetnya masingmasing. ${ }^{30}$ Akal-akal tersebut merupakan simbol malaikat yang diberikan tugas

\footnotetext{
27 Harun Nasution, "Sekitar Pendapat Failasuf Islam tentang Emanasi dan Kekalnya Alam”, Studi Islamika, No. 23 IAIN Syarif Hidayatullah Jakarta, 1986), 5.

${ }^{28}$ Harun Nasution, Islam Ditinjau dari Berbagai Aspeknya (Jakarta: UI-Pres, 2002), 56.

29 Saî̀d Zâyid, al-Farâbî (Kairo: Dar al-Ma'ârif, t.th.), 41 dan 85-86. Hanâ al-Fâkhûrî, Târîkh al-Falsafah al-'Arabîyah, Vol. 2 (Kairo: Dâr al-Ma'ârif, 1957), 113.

${ }^{30}$ Nasution, Akal dan Wabyu, 12.
} 
tambahan oleh Allah. Akal kesepuluh itu disebut akal aktif (aql fa'ấ) dan merupakan malaikat Jibril yang ditugaskan untuk mengatur bumi. ${ }^{31}$

Pada struktur emanasi tersebut dapat dilihat bahwa proses ta'aqqul Tuhan terhadap Dhât-Nya hanya memancarkan akal pertama saja, sedangkan pancaran berikutnya setelah akal pertama dapat memancarkan akal kedua dan langit pertama dan seterusnya. Hal tersebut sejalan dengan prinsip emanasi al-Fârâbî, yaitu yang esa tidak mungkin tercipta darinya kecuali yang satu pula (al-Wâhid lâ yasdur 'anh illâ wâhid). Sebab objek ta'aqqul Tuhan Yang Esa itu hanyalah satu yaitu Dhât-Nya sendiri sehingga darinya pasti hanya menghasilkan satu pancaran saja, yaitu akal pertama.

Konsep pemikiran tersebut dibangun al-Fârâbî untuk menjaga kemurnian tauhid serta menghindari arti banyak pada diri Allah. Sebab secara logis dapat dikemukan bahwa Allah tidak bisa secara langsung dalam menciptakan alam yang banyak sekali jumlah unsurnya (plural). Jika Allah berhubungan secara langsung dalam penciptaan alam yang plural ini maka itu artinya dalam Dhât Allah mengandung arti yang plural pula. Hal ini dapat merusak citra tauhid sebagaimana dalam ajaran Islam. Demikian pula tidak dapat dikemukakan bahwa Allah yang Maha Sempurna berhubungan secara langsung dengan alam yang tidak sempurna. Sebab pemikiran itu secara logis akan merusak citra tauhid dengan menisbatkan ketidak sempurnaan pada Dhât Allah.

Mazhab filsuf-ilmuwan lainnya yang menjelaskan penciptaan alam dengan emanasi adalah Ibn Sînâ. Sejak usia sepuluh tahun dia telah banyak mempelajari ilmu agama Islam dan berhasil menghafal al-Qur'ân. ${ }^{32}$ Ibn Sînâ memiliki paham emanasi yang sama dengan al-Fârâbî, baik dalam segi sistem maupun strukturnya. Secara prinsipil, Ibn Sînâ mengikuti al-Fârâbî bahwa objek ta'aqqul Tuhan itu hanyalah satu, yaitu Dhât-Nya sendiri, sehingga tidak mungkin muncul dari yang satu kecuali satu pula al-Wâhịid lâ yasdur 'anh illâ wâhịid. Namun mereka berbeda dalam menetapkan objek akal-akal. Bagi al-Fârâbî, objek pemikiran akal-akal tersebut ada dua, yaitu Wajỉb al-Wujûd li Dhâtib dan Wajjib alWujûd li ghayrib. Ta'aqqul akal pertama terhadap Tuhan sebagai Wajjib al-Wujûd li Dhatih memancarkan akal kedua, sedangkan ta'aqqul akal pada dirinya sendiri

31 T.J.De Boer, Târikh al-Falsafah fî al-Islâm, terj. Muhammad 'Abd al-Hâdî Abû Raydah (Kairo: Lajnat al-Ta'liff wa al-Tarjamah wa al-Nashr, 1962), 163-164. Nasution, Akal dan Wabyu, 12.

32 Ahmad Daudy, Kuliah Filsafat Islam (Jakarta: Bulan Bintang, 1986), 60 
sebagai Wajiib al-Wujûd li ghayrih menghasilkan langit pertama. Begitu seterusnya dua objek tersebut menghasilkan akal-akal berikutnya dan planet-planetnya.

Bagi Ibn Sînâ, objek pemikiran akal-akal itu ada tiga, yaitu Wâjib al-Wujûd li Dhâtih, Wajiib al-Wujûd li ghayrih, dan mumkin al-wujûd. ${ }^{33}$ Ta'aqqul akal terhadap Allah sebagai Wâjib al-Wujûd li Dhâtih memancarkan akal-akal, sedangkan ta'aqqul akal terhadap dirinya sendiri sebagai Wajibl al-Wujûd li ghayrih menghasilkan jiwa-jiwa, dan ta'aqqul akal terhadap dirinya sendiri sebagai mumkin al-wriûd menghasilkan planet-planet. Proses ini terus berlanjut hingga menghasilkan akal kesepuluh, jiwa, dan planetnya. ${ }^{34}$

Ibn Sînâ tidak menjelaskan lebih jauh tentang akal-akal itu selain sebagai pemberi eksistensi bagi wujud-wujud yang terendah di bawahnya, namun dia menambahkan beberapa fungsi dasar bagi akal kesepuluh. Selain dapat memberikan eksistensi menurut Ibn Sînâ-seperti dikutip Seyyed Hossein Nasr-akal kesepuluh itu dapat memberikan bentuk dalam menggabungkan dengan materi untuk melahirkan makhluk. Setiap makhluk yang dilahirkan diberikan bentuk untuk memungkinkan eksistensinya dan ketika ia binasa bentuk itu ditariknya kembali. Ibn Sînâ menyebut akal kesepuluh itu dengan Wâbib al-S unvar (sang pemberi bentuk). ${ }^{35}$

Selain itu, akal kesepuluh menurut Ibn Sînâ dapat berfungsi mengiluminasi pikiran manusia. Seorang manusia dapat mengabstraksikan dalam pikirannya bentuk-bentuk yang dia diterima dari materi untuk ditingkatkan secara universal melalui pancaran cahaya yang diterimanya dari akal kesepuluh. Karena itu semua bentuk-bentuk alam ini sebenarnya berada dalam pikiran malaikat (angelic mind) yang secara partikular diturunkan ke dunia materi untuk bereksistensi dalam bentuk material untuk dimunculkan kembali dalam pikiran manusia melalui iluminasi menuju tingkatan universal kembali. ${ }^{36}$

Dengan fungsi iluminasi tersebut, Ibn Sînâ memungkinkan akal-akal manusia dapat berkomunikasi dengan akal kesepuluh. Akal manusia yang telah mencapai tingkatan tertinggi, yaitu derajat perolehan (al-mustafâd) dapat mengadakan hubungan dengan akal kesepuluh. Kemungkinan dapatnya komunikasi ini adalah apabila akal manusia telah sangat terlatih dan sangat kuat daya tangkapnya hingga tercapai derajat akal perolehan. Pada pencapaian ini,

\footnotetext{
${ }^{33}$ Harun Nasution, Filsafat dan Mistisme dalam Islam (Jakarta: Bulan Bintang, 1992), 34.

34 Nasr, Tiga Mazhab, 58.

35 Ibid., 59.

${ }^{36}$ Ibid.
} 
akal manusia sudah mampu menangkap hal-hal yang abstrak murni yang diperoleh dari akal kesepuluh. Dengan akal perolehan tersebut, seorang filsuf melakukan komunikasi dengan akal kesepuluh adalah malaikat Jibril. ${ }^{37}$

Ibn Sînâ juga menetapkan fungsi jiwa, yaitu sebagai penggerak planet-planet itu secara langsung. ${ }^{38}$ Setiap planet masing-masing memiliki jiwa yang menggerakkan. Jiwa ini kedudukannya lebih rendah dari pada akal. Pemikiran tentang jiwa ini tidak ada dalam filsafat emanasi al-Fârâbî. Namun, tampak sekali ada kemiripan dengan filsuf lain pendahulunya, yaitu Ibn Miskawayh dan Ikhwân al-Ṣafâ.

Ibn Miskawayh juga sempat membicarakan emanasi dalam metafisikanya. Sebagaimana al-Fârâbî, Miskawayh mengemukakan bahwa entitas yang memancar pertama kali dari Tuhan adalah akal pertama. Miskawayh menyebutnya sebagai akal aktif (aql fa'ẩ), sedangkan al-Fârâbî dan Ibn Sînâ menyebut akal aktif itu adalah akal kesepuluh. Dari akal pertama tersebut muncullah jiwa-jiwa sebagai limpahan kedua, dan planet-planet sebagai limpahan ketiga. ${ }^{39}$

Ikhwân al-Ṣafâa memiliki konsep emanasi yang berbeda, baik dengan pendahulunya. Sistem filsafat emanasi Ikhwân al-Ṣafâ banyak dipengaruhi Plotinus dan Pythagoras. Menurutnya, alam ini diciptakan secara emanasi dari Tuhan sebagaimana angka-angka itu keluar dari angka satu. Allah sendiri adalah Dhât yang maha Esa yang tidak melekat pada-Nya atribut apa pun. Namun, segenap alam ini memancar dari Tuhan melalui akal aktif sebagai entitas pertama yang memancar dari-Nya. Akal aktif ini merupakan cahaya Allah yang keluar sebagaimana keluarnya angka dua dari angka satu. Akal aktif ini mengandung potensi bagi tahapan-tahapan wujud sesudahnya. Oleh karena itu, melalui akal aktif ini Allah menciptakan jiwa universal yang menerima energi dari akal aktif. Jiwa ini selanjutnya mempengaruhi segenap alam semesta, mulai dari yang paling tinggi (al-álam al-úlyâa) sampai yang yang paling rendah (al-âlam

\footnotetext{
${ }^{37}$ Nasution. Akal dan Wabyu, 17.

${ }^{38}$ Nasution, Filsafat dan Mistisme, 34.

${ }^{39}$ Mustofa, Filsafat Islam, 172.

40 Ikhwân al-Ṣafâ sendiri merupakan kelompok Muslim rahasia yang berasal dari sekte Shî‘ah Ismâilîyah di Bashrah. Kelompok ini lahir di tengah-tengah kaum Sunnî sekitar abad kesepuluh Masehi. Mereka melakukan gerakan rahasia untuk mempertahankan semangat berfilsafat dan pemikiran rasional di kalangan pengikutnya. Lihat Sirajuddin Zar, Fisafat Islam: Filsuf dan Filsafatnya (Jakarta: Rajawali, 2010), 138-153.
} 
al-sufâ). Dari jiwa ini terciptalah materi pertama, alam aktif, materi absolut, alam planet-planet, unsur-unsur alam yang paling mendasar seperti tanah, air, udara, dan api, dan materi gabungan yang terdiri dari mineral, tumbuh-tumbuhanhewan, dan manusia. Tahapan-tahapan emanasi tersebut bersama Dhât Allah membentuk angka secara sempurna dari satu sampai sembilan sebagaimana prinsip angka mendasar dalam matematika. Berikut penyajian sederhana sutruktur dan sistem emanasi Ikhwân al-Ṣafâ: Allah sang pencipta, akal aktif (aql fa'ẩ), jiwa universal (al-nafs al-kulliyah), materi pertama (al-hayûlâ al-ûlâ), alam aktif (al-țabîah al-fấilah), materi absolut (al-jism al-mutlaq), alam planet-planet (alâlam al-aflâq), unsur-unsur alam terendah (anâsir al-âlam al-suflâ), dan materi gabungan. ${ }^{41}$

Keterpengaruhan Ikhwân al-Ṣafâ terhadap Pythagoras tampak sekali pada rangkaian angka-angka yang dikemukakannya. Menurut Pythagoras, bilangan itu adalah unsur utama dari alam dan sekaligus menjadi ukuran. ${ }^{42}$ Oleh karena itu bagi Ikhwân al-Ṣafâ wujud akal aktif itu keluar dari Tuhan seperti keluarnya angka dua dari angka satu. Angka satu tersebut merupakan manifes keesaan Tuhan yang memancarkan angka dua sebagai akal aktif, angka tiga sebagai jiwa universal dan seterusnya sampai sempurna menjadi sembilan. Setiap urutan angka itu merupakan penurunan derajat dari angka sebelumnya karena angka satu menempati derajat tertingga sebagai asal dari semua angka sesudahnya. Angka sembilan tersebut juga membentuk bilangan organik dalam tubuh manusia, seperti tulang, sumsum, daging, urat, saraf, darah, kulit, rambut, dan kuku.

\section{Mazhab Emanasi Filsuf-Sufi}

Pada abad kedua belas Masehi muncul pemikiran tasawuf yang bercampur dengan ajaran-ajaran filsafat. Pemikiran ini merupakan corak baru dalam khazanah Islam karena mengompromikan pemakaian termterm filsafat yang maknanya disesuaikan dengan tasawuf, atau sebaliknya mengungkapkan hasil-hasil mistik dengan menggunakan terminologi filosofis. Oleh karena itu, pemikiran tersebut tidak sepenuhnya disebut tasawuf dan tidak pula sepenuhnya disebut filsafat. Banyak pemikir

\footnotetext{
41 Boer, Târikh al-Falsafah, 131.

${ }^{42}$ Amsal Bakhtiar, Filsafat Ilmu (Jakarta: Raja Grafindo Persada, 2012), 26
} 
cenderung menamakannya tasawuf-falsafi, ${ }^{43}$ yakni sebuah terminologi yang mengompromikan visi mistis dengan visi rasional dan berasal dari bermacam-macam konsep yang telah mempengaruhi para tokohnya. ${ }^{44}$ Tokoh-tokohnya masuk dalam pembahasan filsafat dan masuk pula dalam pembahasan tasawuf.

Salah satu tokoh tasawuf falsafi terkemuka yang masuk dalam madzab ini adalah Suhrawardî al-Maqtûl (yang dibunuh). ${ }^{45}$ Suhrawardî telah menyintesiskan sumber yang beragam dalam pemikirannya, baik dari Islam maupun pra-Islam. Elemen Islam paling utama yang mempengaruhi pemikirannya adalah unsur sufisme, terutama karya-karya al-Ḥallaj dan al-Ghazâlî yang menjelaskan adanya relasi antara cahaya dengan keimanan. Selain itu dia terpengaruh juga dengan filsafat Islam parepatetik Ibn Sînâ meski dia sendiri mengritisi beberapa bagian di dalamnya. Dari elemen pra-Islam, dia dipengaruhi oleh Pythagoras, Platonisme, Hermenisme, Zoroaster, dan pemikiran-pemikiran (hikmah) Persia kuno. Bahkan Suhrawardî menganggap dirinya sebagai titik pusat pertemuan dua cabang hikmah dunia. Salah satu cabang di antaranya terbagi ke Persia melalui raja-raja dan pendeta Persia, dan cabang lainnya terbagi ke mesir yang kemudian melebar ke Yunani melalui Pythagoras, Plato, dan Platonisme. Dua hikmah tersebut diyakininya berasal dari Nabi Idris (Hermes) yang diklaim bertemu dalam diri Suhrawardî dan membentuk pemikirannya yang paling utama, yaitu ishrâq (iluminasi). ${ }^{46}$

Al-Ishrâq merupakan konsep utama Suhrawardî dalam membangun tasawuf falsafinya, di mana ia sebenarnya masih tergolong dalam aliran emanasi. Kata al-ishrâq mempunyai banyak arti antara lain: terbit, bersinar atau memancarkan cahaya. Ishrâq berkaitan dengan cahaya, yang pada umumnya digunakan sebagai lambang kekuatan, kebahagiaan,

43 Amin Syukur, Menggugat Tasannf: Sufisme dan Tanggung Jawab Sosial Abad 21 (Yogayakarta: Pustaka Pelajar, 2012), 39.

44 Abu Al-Wafa' al-Ghanimi al-Taftazani, Sufi dari Zaman ke Zaman, terj. Ahmad Far'i Ustmani (Bandung: Pustaka Setia, 1985), 187.

45 Suhrawardî yang bernama lengkap Shihâb al-Dîn Yaḥyâ b. Hạashî b. Amîrak alSuhrawardî dilahirkan pada tahun 549 H/1153 M di desa Suhraward di kawasan Persia dan meninggal pada usia 38 tahun. Dia memiliki sejumlah nama panggilan, yaitu Shaykh al-Ishrâq, al-Hakîm, al-Shabîd, dan yang paling terkenal adalah al-Maqtûl. Penyebutan alMaqtûl di belakang namanya terkait dengan proses meninggalnya setelah dijebloskan ke dalam penjara oleh Sultan Shalahuddin al-Ayubi sebagai respons atas reaksi pemahaman para fuqoha' yang menentang pemikirannya. Lihat Nasr, Tiga Mą̧ hab, 105-107.

46 Ibid., 111-115. 
ketenangan, dan hal-hal lain yang membahagiakan. Lawannya adalah kegelapan, yang dijadikan lambang keburukan, kesusahan, kerendahan dan semua hal yang membuat manusia menderita. Kata ishrâq dalam bahasa Inggris mempunya arti Illumination. ${ }^{47}$

Menurut Suhrawardi, seperti dikutip oleh Sayyed Hussein Nasr, bahwa seluruh realitas ini tak lain dari cahaya yang memiliki beragam tingkatan dan intensitas. Ia tidak memerlukan definisi karena kebiasaan definisi dihadirkan untuk menjelaskan ketidak jelasan sesuatu, sedangkan tak ada yang lebih jelas dan lebih jernih dari cahaya. ${ }^{48}$ Kosmos ini menurutnya terdiri dari susunan hierarki cahaya. Konsep al-ishrâq ini menyatakan, bahwa alam ini diciptakan melalui penyinaran atau pancaran cahaya (iluminasi) dengan proses yang hampir sama dengan emanasi (alfayd) yang dikembangkan oleh Al-Fârâbî dan Ibn Sînâ. Sumber dari segala yang realitas itu adalah Cahaya Yang Mutlak, yaitu cahaya tertinggi yang ia sebut dengan $N \hat{r}$ al-Anwâr atau Nûr al-A'zam. Ia merupakan esensi Tuhan yang azali dan menyilaukan segala eksistensi. Manusia berasal dari Nûr al-Anwâr yang diciptakan melalui pancaran cahaya. Oleh karena itu, terjadi relasi arus bolak-balik antara Tuhan dengan manusia, baik dari atas ke bawah yang membentuk seperti paham al-Hulûl dalam pemikiran al-Hallâj dan dari bawah ke atas yang membentuk seperti paham al-Ittiḩâd sebagaimana dalam pemikiran Abû Yazîd al-Bistâmî. ${ }^{49}$

Karena segala realitas ini adalah cahaya maka ia membentuk susunan hierarki-hierarki wujud dari yang tertinggi sampai yang terendah sebagaimana emanasi al-Fârâbî dan Ibn Sînâ. Hanya saja Suhrawardî tidak memberikan batasan tertentu bagi susunan hierarki tersebut sebagaimana al-Fârâbî dan Ibn Sînâ yang membatasi hingga akal kesepuluh saja dengan planet-planetnya. Cahaya tertinggi dalam susunan hierarki itu adalah esensi Tuhan yang maha esa dan maha sempurna. Ia adalah Allah yang merupakan sumber segala cahaya dan menjadi penyebab segenap susunan hierarki wujud tersebut. Semakin dekat suatu hierarki wujud pada sumber cahaya, maka intensitas cahayanya akan lebih banyak. Semakin jauh dari sumber cahaya, maka akan lebih sedikit intensitas cahaya yang diterimanya. Wujud yang lebih dekat kepada

${ }^{47}$ Jamîl Ṣalîbâ, al-Mu jam Falsafî, Vol. 1 (Beirut: Dâr al-Kitab al-Lubnânî, 1982), 93-94.

${ }^{48}$ Nasr, Tiga Mazhab, 126.

49 Rivay Siregar, Tasanuf dari Sufisme Klasike ke Neo-Sufisme (Jakarta: Grafindo Persada, 2002), 164-169. 
Tuhan sebagai sumber cahaya akan lebih banyak menerima pancaran dari-Nya, sementara wujud yang jauh dari-Nya semakin lemah intensitas cahayanya. Dengan demikian makin rendah tingkatan dalam hierarki keberadaannya. ${ }^{50}$

Dalam upaya mengungkap kosmologi, Suhrawardî sejalan dengan alFârâbî yang meyakini bahwa dari Dhât tunggal hanya memancarkan satu bentuk yang tunggal. Maka Nûr al-Anwâr sebagai sumber penciptaan hanya memancarkan cahaya-Nya pada satu cahaya murni, yang juga memiliki sifat kesamaan dengan Nûr al-Anwâr. Pemancaran cahaya ini diakibatkan oleh aktivitas Nûr al-Anwâr yang senantiasa memancarkan cahaya dari substansinya. Sebagai hasil pemancaran cahaya substansinya terjadilah satu pelimpahan atau emanasi pada Cahaya Murni pertama dan dibarengi dengan satu materi alam abadi (yang disebut dengan Huyuli) yang menjadi materi dasar pembentuk alam semesta. Cahaya Murni pertama ini, seperti Nûr al-Anwâr, dicirikan oleh aktivitasnya yang serupa, yaitu menerima pancaran cahaya Nûr al-Anwâr dan memancarkan Cahaya-Nya kembali dari substansinya. Walaupun demikian keduanya tetap memiliki perbedaan fundamental, baik dalam Dhât ataupun strata fungsionalnya.

Suhrawardî mengawali sekaligus mengakhiri sufi falsafi yang bermazhab emanasi di dunia Timur karena corak pemikiran ini selanjutnya berpindah ke Barat dengan kemunculan Ibn 'Arabî di Andalusia. ${ }^{51}$ Di Barat dia dikenal dengan Ibn 'Arabî, sedangkan murid-

${ }^{50}$ Haidar Baqir, Buku Saku Filsafat Islam (Bandung: Mizan, 2005), 140 .
51 Ibn 'Arabî dilahirkan $1163 \mathrm{M}$ di Murcia, bagian tenggara Andalusia dan meninggal
pada usia 78 tahun. Bahkan melebihi Suhrawardî dalam kemasyhuran, dia dianggap
sebagai icon dari kemajuan tasawuf falsafi yang muncul pada abad ke-6 H, meskipun
disebut-sebut bahwa awal kemunculan tasawuf falsafi adalah dari pemikiran Ibn
Masarrah (w. $319 \mathrm{H} / 1931 \mathrm{M}$ ), seorang tokoh sufi yang juga memiliki pengaruh yang
besar di Andalusia. Lihat M. Solihin dan Rosihon Anwar, Ilmu Tasawnf (Bandung:
Pusataka Setia, 2011), 70 .
Ibn 'Arabî banyak berkunjung ke berbagai kota di Andalusia dan Afrika Utara untuk
belajar pada banyak guru dengan tanpa peduli latar belakang mereka, baik filsuf, teolog,
sufi, dan lain-lain. Petualangan tersebut membuatnya menjadi sosok pemikir yang
kompleks, dengan banyak bidang keilmuan yang dikuasasinya, khususnya tasawuf dan
filsafat. Dia juga dikenal sebagai seorang penyair yang produktif. Ribuan halaman telah
lahir dari tangannya berupa karya-karyanya yang banyak, baik berbentuk ensiklopedi
maupun risalah-risalahnya tentang ajaran-ajaran tasawuf. Beberapa kitabnya antara lain:
al-Kibrît al-Aḥmar, al-Isrâ ilâ Maqâm al-Isrâ, Asrâr Umm al-Qur'ân, Asrar al-Qulûb, Asrâr al- 
muridnya memanggilnya Muby al-Dîn (penghidup agama), sehingga dikenal Muhy al-Dîn Ibn 'Arabî atau Ibn 'Arabî saja. Orang-orang yang kurang menyukai pemikirannya memberi julukan mâḥ̂ al-dîn" (penghapus agama) atau mumit al-dîn (yang mematikan agama). ${ }^{52}$ Panggilan tersebut terkait dengan pemikirannya yang dianggap kontroversial di kalangan Sunnî. Selain itu, Ibn 'Arabî juga diberi gelar alShaykh al-Akbar (doktor maximus). Gelar lain yang disandangnya adalah al-Qutb, al-Ghauth, atau al-Kibrît al-Aḥmar.53 Dia juga dijuluki Ibn Aflâtûn (putra Plato). ${ }^{54}$ Dari julukan yang terakhir ini jelas sekali memperlihatkan adanya pengaruh plato dan platonisme dalam pemikirannya.

Pemikirannya tentang emanasi dituangkan dalam dua buah karya besarnya, al-Futûhât al-Makekîyah dan Fuṣ̂ș al-Hikam. Dua buah karya itu merupakan saksi ketajaman intelektual dan kedalaman penghayatan mistiknya yang diperoleh melalui pendakian-pendakian spiritual. Bahkan diklaim bahwa kitab Fușus al-Hikam ditulis atas perintah nabi Muhammad, sedangkan al-Futûhât al-Makkîyah mendapat perintah Allah dalam sebuah perjalanan spiritual. Dalam kitab tersebut, Ibn 'Arabî mengulas dengan panjang hubungan alam dengan Tuhan secara emanasi, namun lebih dikemas dengan konsep waḥdat al-wujûd. Kerangka emanasi sendiri dituangkan dalam kitabnya Shajarat al-Kawn. Kitab ini kecil dan sangat ringkas namun lebih jelas dalam menggambarkan bentuk dan sistem emanasi Ibn 'Arabî. Dalam kitab ini, Ibn 'Arabî mengulas pandangannya tentang kesatuan wujud melalui emanasi yang dituangkan dalam bentuk simbol-simbol eksistensi yang berhasil memadu pemikiran tasawuf dan filsafat dengan ilmu-ilmu keislaman, khususnya al-Qur'ân dan hadîth.

Menurut Ibn 'Arabî, eksistensi alam semesta muncul dari sebuah titik firman Allah berupa “kun” sebagaimana dalam al-Qur'ân surah al-Naḥl:

Waby fî al-Mi'râj, Mashâhid al-Asrâr al-Qudsîyah wa Matâli' al-Anwâr al-Ilâhîyah, Miskât alAnwâr, Mawâai al-Nujûm, Tâj al-Rasẩil, Kitab Jalâl wa al-Jamâl, Kitab al-Tajalliyât, dan masih banyak lagi karya-karya Ibn 'Arabî yang lain. Lihat M. Fudoli Zaini, Sepintas Sastra Sufi Tokoh dan Pemikirannya (Surabaya: Risalah Gusti, 2000), 18-19.

${ }^{5}$ Henry Corbin, Imajinasi Kreatif Sufisme Ibn 'Arabî, terj. Moh. Khosim dan Suhadi (Yogyakarta: LKiS, 2002), 80.

53 Ahmad Isa, Tokob-tokob Sufi: Tauladan dan Kehidupan yang Shaleb (Jakarta: PT Raja Grafindo Persaada, 2000), 203.

${ }^{54}$ Corbin, Imajinasi Kreatif, 31. 
40. Dia menyimbolkan segala eksistensi ini seperti pohon yang batangnya keluar dari sebuah benih perintah ilahiyah berupa kun itu. Firman kun dalam pandangan Ibn 'Arabî merupakan manifestasi dari kâf al-kawnîyah dan nûn al-anânîyah. Dari dua realitas ini munculah alam semesta melalui sebuah perkawinan kosmik antara keduanya. Perkawinan kosmik itu menghasilkan alam-alam berikutnya, seperti alam ruh, alam jiwa, alam bentuk, dan alam fisik. Sistem emanasi Ibn arabi ini dapat dilihat dalam struktur berikut: Dhât Allah, Nûn al-Anânîyah (esensi ke-aku-an), Kâf alKawnŷyah (esensi potensi eksistensial), 'Âlam al-Rûh (alam ruh), 'Âlam alNufûs (alam jiwa), 'Alam al-Mîthâl (alam bentuk), dan 'Âlam al-Ajsâm (alam materi).

Ibn 'Arabî menjelaskan bahwa entitas pertama yang menetes dari Tuhan adalah nun al-anânîyah. Dia menyebut pancaran pertama ini dengan istilah al-fayd al-aqdas (pancaran paling suci) karena ia yang pertama kali memancar secara murni dari Dhât yang maha esa. Entitas pertama ini hakikatnya adalah Nur Muhammad sebagai ciptaan murni yang pertama melalui emanasi. Lebih lanjut Ibn 'Arabî memandang pancaran perama ini dengan akal universal (al-'aql al-kulliyah). Dengan demikian Ibn 'Arabî telah memadukan terminolagi mistik seperti dalam ajarannya dengan terminologi filsafat Plotinus.

Entitas kedua yang mumancar dari Tuhan adalah nûn al-anânîyah. Pancaran kedua ini disebut dengan al-Fayd al-Muqaddas (pancaran yang suci) dan memancar melalui al-Fayd al-Aqdas. Pada tahapan ini sesuatu yang akan bereksistensi mulai tertulis dalam dunia potensial. Oleh karena itu, Ibn 'Arabî menyebutnya dengan A'yân al-Thâbitah (entitas-entitas permanen) dan jiwa universal (al-Nafs al-Kulliyah) sebagaimana filsafat Plotinus. Disebut entitas-entitas permanen karena segala macam eksistensi dalam tahapan ini masih merupakan potensi yang belum bereksistensi, tapi masih akan bereksistensi. Melalui tahapan inilah Tuhan memancaran berikutnya yang disebut dengan al-Fayd al-Daim (pancaran yang terus-menerus). Disebut demikian karena segala realitas yang masih menjadi potensi dalam $A^{\prime} y$ ân al-Thâbitah itu keluar untuk menjadi bentukbentuk eksistensi dalam alam semesta dan ini disebut dengan ciptaan yang terus menerus. Ibn 'Arabî menyebut tahapan ini pula dengan A'yân al-Khârijîyah (entitas-enitas yang keluar) di mana susunan alam semesta ini muncul secara bertahap mulai dari alam ruh, alam jiwa, alam bentuk, dan alam materi. 


\section{Implikasi Teologis Teori Emanasi}

Apa yang telah dikemukakan oleh para filsuf tersebut masih merupakan hasil spekulasi dan kontemplasi sehingga menghasilkan konsepsi yang beragam sesuai latar belakang yang mempengaruhi para tokohnya. Jika konsep-konsep tersebut dihadapkan pada kosmologi modern seperti yang dikembangkan ilmu pengetahuan maka hal tersebut akan memberikan fakta-fakta yang berbeda, terutama bagi para filsuf ilmuwan. Sebab emanasi dikembangkan mazhab tersebut sesuai dengan perkembangan ilmu pengetahuan yang ada pada saat itu. Namun demikian, pemikiran emanasi para filsuf ini menjadi kajian yang menarik pada masa itu karena di samping memiliki unsur-unsur rasionalitas dan mistik, juga memiliki implikasi teologis. Sebab sejak semula pengembangan di bidang ini adalah untuk membentengi ajaran Islam dengan logika Aristoteles dan filsafat Yunani lainnya. Meski beberapa yang mereka kembangkan tersebut dianggap membahayakan kajiankajian teologi murni yang bersumber dari agama.

Secara umum, konsep emanasi ini memiliki prinsip yang sama dalam memberikan kesan tauhid. Bahwa dari Yang Maha Esa hanya memunculkan satu entitas murni sebagai emanasi pertama. Al-Fârâbî dan Ibn Sînâ menyatakan emanasi pertama itu adalah akal pertama, Ibn Miskawayh dan Ikhwân al-Ṣafâ menyebutnya dengan akal aktif (al-'aql alfa'âl), dan Suhrawardî menyebutnya cahaya murni (Nûr al-Aqrab). Sedangkan Ibn 'Arabî menyebutnya dengan Nur Muhammad dalam bahasa mistiknya atau akal universal dalam terminologi filsafat sebagai terjemahan dari nûn al-anânîyah dalam firman Tuhan yang berupa Kun. Semua itu memberikan kesimpulan yang sama bahwa dari Tuhan Yang Maha Esa hanya terjadi satu kali emanasi saja.

Perbedaannya terletak pada persoalan, apakah alam ini diciptakan dari ada atau tiada? Para filsuf dua mazhab ini berpendirian sama bahwa alam diciptakan Tuhan dari ada, kecuali Ibn Miskawayh yang menyatakan sebaliknya, bahwa alam diciptakan dari tiada. ${ }^{5}$ Tanpa takwil sama sekali, Ibn Miskawayh menyatakan bahwa segala sesuatu itu diciptakan dari awal. Dalam artian bahwa segala sesuatu itu diciptakan dari tiada ('adam). Sebab tidak ada artinya mencipta jika yang diciptakan telah mempunyai

55 Zar, Filsafat Islam, 131. 
wujud sebelumnya. Pendapat demikian sejalan dengan pendapat para teolog, terutama dari kalangan Ahl al-Sunnah. ${ }^{56}$

Bagi para filsuf dari dua mazhab ini, konsep emanasi memiliki konsekuensi logis bagi munculnya suatu pendapat bahwa alam ini diciptakan dari ada. Sebab emanasi itu tidak mungkin muncul kecuali dari ada. Akal-akal dalam pemikiran para filsuf muncul dari ada, keberadaan dalam dunia potensi. Dalam dunia potensi sesuatu itu belum ada, tapi akan mengada. Bahkan Ibn 'Arabî mempunyai istilah sendiri dalam mengungkapkan masalah ini dengan A'yân Thâbitah (entitas-entitas permanen). Di katakan permanen karena entitas itu belum muncul dalam dunia eksistensi. Oleh karena itu, perintah ilahiyah kun dalam al-Qur'ân ditujukan kepada shay' (sesuatu yang ada), bukan kepada lâ shay' (sesuatu yang tidak ada). ${ }^{57}$ Pendapat serupa dapat ditemukan pada kaum teolog Mu'tazilah.

Mu'tazilah sebenarnya berpendapat bahwa alam ini diciptakan dari tiada ('adam), tetapi tidak seperti Ibn Miskawayh, mereka masih melanjutkan pendapat itu dengan memberikan penakwilan. Menurut mereka yang dimaksud dengan 'adam itu bukan ketiadaan muktlak, tetapi keberadaan dalam dunia potensi dan yang ada dalam dunia potensi itu adalah materi alam semesta. Mereka mengemukakan argumentasi bahwa hal yang ma'dûm (tiada) itu dapat diklasifikasi menjadi dua bagian, yaitu ma'dûm mumkin dan ma'dûm ghayr mumkin. Ma'dûm mumkin merupakan ketiadaan yang masih dimungkinkan keberadaanya dan hal ini disebut dengan shay' sebagaimana yang ada dalam al-Qur'ân surah al-Naḥl: 40. Sedangkan ma'dûm ghayr mumkin tidak mungkin mengada dan tidak dapat disebut dengan shay' (sesuatu). ${ }^{58}$ Takwil seperti ini tidak ada dalam pendapat Ibn Miskawayh.

Menurut Mu'tazilah, bahwa setiap benda (jism) itu terdiri dari materi yang diperoleh dari adam (keberadaan mumkin dalam dunia potensi) dan dari wujud yang bersumber dari Allah. Dengan demikian 'adam adalah materi alam, sedangkan wujud adalah bentuknya. Pendapat ini

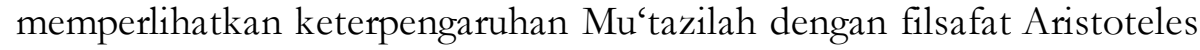
tentang matter (materi yang abadi) dan form (bentuk), sebagaimana para

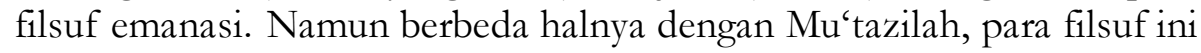

\footnotetext{
${ }^{56}$ Mustofa, Filsafat Islam, 171-172

${ }^{57}$ Zar, Filsafat Islam, 74.

${ }^{58}$ Mustofa, Filsafat Islam, 75.
} 
menyatakan materi itu diperoleh dari keberadaan dalam dunia potensi, sedangkan bentuknya (form) diperoleh dari akal aktif. Bahwa akal aktif (al'aql al-fa 'ẩ) yang memberi bentuk (wâhib al-șuwar) kepada suatu wujud dan merubahnya kepada bentuk-bentuk yang lain sebagaimana yang dikemukakan Ibn Sînâ. 59

Pendapat filsuf emanasi bahwa alam diciptakan dari ada menimbulkan persoalan baru. Sebagai konsekuensi logisnya adalah alam ini diciptakan secara emanasi dari ada tanpa diselingi oleh waktu dan tanpa permulaan. Sebab keberadaan dalam dunia potensi itu mengharuskan keberadaan yang tak bermula. Dengan demikian alam ini qadîm. Namun menurut mereka antara qadîm Allah dengan qadîm alam ini terdapat perbedaan besar, yaitu terletak pada Dhât (taqaddum Dhâti). Esensi Allah sebagai pencipta yang memancarkan alam lebih dulu dari pada esensi alam itu sendiri. Karena Allah adalah sebab bagi adanya pancaran alam itu, maka qadîm alam masih bergantung dengan qadîm Tuhan. Sedangkan dari segi zaman (taqaddum zamânî) alam ini diciptakan dalam waktu yang tak bermula.

Emanasi Ibn 'Arabî sedikit memberikan ulasan yang berbeda dalam hal ini. Secara sederhana emanasi Ibn 'Arabî memiliki tiga struktur ontologis (marâtib al-wujûd), yaitu Dhât Tuhan, $A^{\prime} y a ̂ n$ Thâbitah, dan $A^{\prime} y a ̂ n$ Kharijiyah. Dhât Tuhan itu qadîm dan $A^{\prime} y a ̂ n$ Kharijìyah itu baru. Sedangkan A'yân Thâbitah yang esensinya menyimpan potensi entitas-entitas yang akan keluar (A'yân Kharijîyah) diposisikan antara qadîm dan baru. Menurut Ibn 'Arabî, ia adalah qadìm jika dikaitkan dengan objek pengetahuan Tuhan yang azali, namun jika dihubungan dengan eksistensi alam yang diciptakan ia adalah baru. ${ }^{60}$

Konsep emanasi juga melahirkan kesimpulan bahwa pengetahuan Tuhan tidak berhubungan secara langsung dengan perincian-perincian alam semesta. Pendapat ini sebenarnya ditujukan untuk menjadi landasan tauhid dan menghindari adanya hubungan Tuhan secara langsung dengan alam. Sebab bagi para filsuf Tuhan yang Maha Sempurna tidak dapat dihubungkan secara langsung dengan alam yang tidak sempurna sebagaimana emanasi mereka yang berusaha menjaga keesaan Tuhan

\footnotetext{
59 Ibid., 72.

60 Ibnu Ali, "Konsep Emanasi dalam Tasawuf Eksistensial Ibn Arabi: Studi Hermeneutika dalam Kitab Shajarat al-Kann" (Tesis--UIN Sunan Ampel Surabaya, 2014), 79.
} 
dalam pikiran dari adanya pluralitas alam. Meski upaya-upaya para filsuf emanasi itu adalah untuk menjaga kemurnian tauhid, namun pendapatpendapat mereka mendapat kritikan keras dari al-Ghazâlî, filsuf yang berkonsistensi dengan ilmu kalam. Bahkan menurut al-Ghazâlî, pendapat-pendapat kaum filsuf emanasi itu membuat mereka kafir. ${ }^{61}$

\section{Catatan Akhir}

Persentuhan filsafat dengan Islam melahirkan mazhab baru yang memisahkan diri dari filsafat Yunani. Filsafat Islam merupakan hasil dialog antara rasionalitas akal murni dengan dokrin agama (Islam). Para tokohnya dipengaruhi unsur-unsur ilmu pra-Islam, baik dari Yunani maupun Persia. Latar belakang tokohnya yang beragam itu melahirkan konsep pemikiran emanasi yang beragam pula. Mulai dari al-Fârâbî, Ibn Miskawayh, Ikhwân al-Ṣafâ, dan Ibn Sînâ merupakan filsuf emanasi dengan latar belakang ilmu pengetahuan. Mereka tergolong mazhab filsuf-ilmuwan meski ada perbedaan konsep sesuai dengan latar belakang ilmu yang mereka terima. Sedangkan Suhrawardî al-Maqtûl dan Ibn 'Arabî merupakan filsuf emanasi dengan latar belakang tasawuf yang berpijak dari pengetahuan intuitif. Meski berbeda-beda dalam cara pengungkapan, namun pada prinsipnya adalah sama-sama emanasi.

Pemikiran emanasi ini memiliki implikasi teologis yang sama, meski berbeda-beda dalam konsepnya. Implikasi teologisnya itu ditujukan untuk menjaga kemurnian paham tauhid dengan argument-argumen filosofis. Bahkan argumen mereka lebih radikal daripada teologi rasional Mu'tazilah.

\section{Daftar Rujukan}

Ahwânî (al), Fuâd. al-Falsafah al-Islâmîyah. Kairo: Dâr al-Qalam, t.th.

Ali, Ibnu. "Konsep Emanasi dalam Tasawuf Eksistensial Ibn Arabi:

Studi Hermeneutika dalam Kitab Shajarat al-Kawn". Tesis--UIN Sunan Ampel Surabaya, 2014.

al-Taftazani, Abu Al-Wafa' al-Ghanimi. Sufi dari Zaman ke Zaman, terj.

Ahmad Far'i Ustmani. Bandung: Pustaka Setia, 1985.

Bakhtiar, Amsal. Filsafat Ilmu. Jakarta: Raja Grafindo Persada, 2012.

Baqir, Haidar. Buku Saku Filsafat Islam. Bandung: Mizan, 2005.

${ }^{61}$ Nasution, Islam Ditinjau, 62. 
Boer, T.J.De. Târîkh al-Falsafah fî al-Islâm, terj. Muhammad 'Abd al-Hâdî Abû Raydah. Kairo: Lajnat al-Ta'lîf wa al-Tarjamah wa al-Nashr, 1962.

Corbin, Henry. Imajinasi Kreatif Sufisme Ibn 'Arab̂, terj. Moh. Khosim dan Suhadi. Yogyakarta: LKiS, 2002.

Daudy, Ahmad. Kuliah Filsafat Islam. Jakarta: Bulan Bintang, 1986.

Fâkhûrî (al), Hanâ. Târîkh al-Falsafah al-'Arabîyah, Vol. 2. Kairo: Dâr alMa'ârif, 1957.

Gazalba, Sidi. Sistematika Filsafat. Jakarta: Bulan Bintang, 1976.

Hakim, Atang Abdul. Filsafat Umum: dari Mitologi sampai Teofilsofi. Bandung: Pustaka Setia, 2008.

Hanafi, A. Pengantar Filsafat Islam. Jakarta: Bulan Bintang, 1976.

Hilal, Ibrahim. Tasawuf antara Agama dan Filsafat: Sebuah Kritik Metodologis, terj. Ija Suntana dan E. Kusdian. Bandung: Pustaka Pelajar, 2002.

Isa, Ahmad. Tokoh-tokoh Sufi: Tauladan dan Kehidupan yang Shaleh. Jakarta: PT Raja Grafindo Persaada, 2000.

Khan, Khan Sahib Khaja. Cakrawala Tasawuf, terj. Achmad Nashir Budiman. Jakarta: Raja Grafindo Persada, 1993.

Madjid, Nurcholish. Khazanah Intelektual Islam. Jakarta: Bulan Bintang, 1984.

Mustofa, A. Filsafat Islam. Bandung: Pustaka Setia, 1997.

Nasr, Seyyed Hossein. Tiga Mą̧bab Utama Filsafat Islam: Ibnu Sina, Subrawardi, dan Ibn Arabi. Yogyakarta: IRCiSoD, 2014.

Nasution, Harun. "Sekitar Pendapat Failasuf Islam tentang Emanasi dan Kekalnya Alam", Studi Islamika, No. 23 IAIN Syarif Hidayatullah Jakarta, 1986.

Nasution, Harun. Akal dan Wabyu dalam Islam. Jakarta: UI-Press, 1986.

-----. Filsafat dan Mistisme dalam Islam. Jakarta: Bulan Bintang, 1992.

----. Islam Ditinjau dari Berbagai Aspeknya. Jakarta: UI-Pres, 2002.

----. Teologi Islam: Aliran-aliran Sejarah Analisa Perbandingan. Jakarta: UI Press, 2012.

Șalîbâ, Jamîl. al-Mu'jam Falsafî, Vol. 1. Beirut: Dâr al-Kitab al-Lubnânî, 1982.

Sa'îd Zâyid, al-Farâbî. Kairo: Dar al-Ma'ârif, t.th.

Siregar, Rivay. Tasawuf dari Sufisme Klasike ke Neo-Sufisme. Jakarta: Grafindo Persada, 2002. 
Solihin, M. dan Anwar, Rosihon. Ilmu Tasawuf. Bandung: Pusataka Setia, 2011.

Syukur, Amin. Menggugat Tasawuf: Sufisme dan Tanggung Jawab Sosial Abad 21. Yogayakarta: Pustaka Pelajar, 2012.

Zaini, M. Fudoli. Sepintas Sastra Sufi Tokoh dan Pemikirannya. Surabaya: Risalah Gusti, 2000.

Zar, Sirajuddin. Fisafat Islam: Filsuf dan Filsafatnya. Jakarta: Rajawali, 2010. 